ISSN 0554-6397

UDK: 338.2:504.42.064](497.5)

$338.48-44(26)(497.5)$

Review article

Received: 10.09.2019.

\author{
Alen Alempijević \\ E-mail: alen.alempijevic@pomorstvo.hr \\ Ministarstvo mora, prometa i infrastrukture, Uprava sigurnosti plovidbe, Zagreb \\ Mirjana Kovačić \\ E-mail: mirjana051@gmail.com \\ Sveučilište u Rijeci, Pomorski fakultet, Rijeka
}

\title{
Nautical Tourism and Small Shipbuilding as Significant part of Blue Economy Development
}

\begin{abstract}
Nautical tourism is one of the major tourism sectors and the largest growing maritime industry in Europe, employing almost 3.2 million people. Nautical tourism is of great importance for Croatia and Croatia is increasingly promoted as one of the leading Mediterranean nautical destinations. Croatia's insular and coastal nautical infrastructure offers its users adequate services, but services need to be continuously upgraded. At the same time, the development of the local community must not be subordinated to the development of a nautical destination.

The authors analyze nautical tourism and small shipbuilding, two sectors that constitute the blue economy. The blue economy is analyzed with particular regard as a long-term strategy to support the sustainable growth of the marine and maritime sectors. The authors emphasize that the blue economy aims to stimulate sustainable economic development, create business opportunities and open jobs in the blue economy sectors of the EU countries. The importance of the blue economy for Croatia is analyzed and the results of the analysis presented.
\end{abstract}

Keywords: blue growth, nautical and maritime tourism, small shipbuilding, sustainable economical development, Croatia

\section{Introduction}

The blue economy represents all economic activities related to the oceans, seas or coastal areas to be developed with the aim of boosting economic growth and development, increasing jobs and improving the environment while preserving the eco system. It covers sectors such as fisheries, shipbuilding and tourism as well as some emerging industries such as ocean energy and biotechnology.

The research problem was determined to address the policy of the development of small shipbuilding and nautical tourism in Croatia. The research problem has set the framework for determining the subject of the research: to explore the European 
Union strategy and the national strategy for realizing sustainable development and development of nautical tourism through the blue economy. The research problem and the subject of the research relate to the following research objects: guidelines and legal framework, EU incentives and projects and financial statements and other statistics as indicators of the growth of the blue economy.

In relation to the problem, the subject and object of the scientific research, the purpose and objectives of the research have been determined: the authors analyze the importance of the development of nautical tourism and small shipbuilding, as future bearers of economic development in Croatia.

\section{The Notion of Blue Growth}

This chapter explains the European Union (EU) action to promote the economic development of marine and maritime sectors by introducing a long-term strategy to support their sustainable growth. In its 2010 Communication, the Commission announced a strategy for sustainable coastal and maritime tourism. The European Parliament, the Council, the Committee of the Regions and the European Economic and Social Committee welcomed this proposal and emphasized the need for joint action. The public consultation held in 2012 provided a strong basis for a special EU initiative. Furthermore, the 2012 Blue Growth Communication lists the coastal and maritime tourism as one of the five key areas for sustainable growth and jobs in the blue economy. The European Parliament Blue Growth Communication of 2014 recommended a series of measures to boost the sector and support the development of sustainable tourism in coastal destinations [7].

Blue growth is a long-term strategy to support the sustainable growth of the marine and maritime sectors and it aims to stimulate the sustainable economic development and create business opportunities and new jobs in "blue" economic sectors such as fisheries and aquaculture. Some of the priorities under this pillar are: efficient use of resources in fisheries and encouraging the production and consumption of food from the sea; improving the business environment and enhancing the competitiveness of the maritime economy through institutional and infrastructure support; support for research, development and applied innovation in the maritime industry and investment in the development of human resources.

The seas and oceans are the drivers of the European economy and have great potential for innovation and growth. They are a maritime contribution to achieving the Europe 2020 goals for smart, sustainable and inclusive growth [5]. The blue economy employs around 5.6 million people and produces a gross value added (GVA) of EUR 495 billion annually.

According to the newest research, Blue economy is an integration of sustainable development and green growth [8, 4]. It highlights an overall-planning and coordinated development between the marine ecosystem and the ocean and coastal zone economic system. 
The Integrated Maritime Policy, representing harmonized policies of EU countries, covers diverse areas such as fisheries and aquaculture, shipping and seaports, marine environment, marine research, offshore energy sources, shipbuilding and maritime industries, maritime surveillance, maritime and coastal tourism, employment, coastal region development and maritime external relations. The guidelines for implementing the European Commission's Blue Growth Strategy are as follows:

1. Developing sectors with high potential for growth and sustainable jobs, such as aquaculture, coastal tourism, marine biotechnology, ocean and offshore energy.

2. Ensure the provision of knowledge, legal regulatory compliance and stability in the blue economy: maritime knowledge to improve access to marine information; maritime spatial planning to ensure efficient and sustainable management of maritime activities; and integrated maritime surveillance to give authorities a better picture of what is happening at sea.

3. Provide marine development strategies to ensure implementation of the measures and to promote interstate cooperation: Adriatic and Ionian Seas, Arctic Ocean, Atlantic Ocean, Baltic Sea, Black Sea, Mediterranean Sea and North Sea [5].

The most profitable investments are in the coastal tourism sector with EUR 183 billion in GVA per year or aquaculture, then in the developing sector, such as marine biotechnology with an annual GVA of EUR 14.1 billion, and in promising sectors such as deep-sea mining or ocean energies that have enormous potential for employment [4]. Tourism is expected to grow at an average annual rate of $2 \%$ to $3 \%$ (the cruise industry is projected to grow by $60 \%$ in this decade and to create 100,000 jobs) and predicts a nearly tenfold growth in the renewable ocean energy before 2020 (offshore wind power sector is expected to grow intensively from 35,000 jobs in 2010 to possible 170,000 by 2020 ), and worldwide offshore mining could grow exponentially in the next ten years. Blue growth can bring real, sensible and positive change to the European economy [4].

Nautical and maritime tourism is the most important tourism sub-sector and the largest maritime industry in Europe, employing almost 3.2 million people. In this regard, Europe, as the world's leading nautical destination, must improve its island and coastal tourism infrastructure. This sector also includes 'inland' nautical tourism which is present in many Member States on lakes, rivers, etc. and should also be taken into account in the review process. It includes a large shipbuilding industry as well, comprising the construction of yachts, pleasure boats and cruise ships, in which Europe has a prominent role at the level of the world economy.

\section{European Union Strategy for the Adriatic - Ionian Region (EUSAIR)}

The Adriatic - Ionian region is located at an important European crossroads with rich cultural and natural heritage, and covers a total of eight countries: Greece, Italy, Slovenia, Croatia, Bosnia and Herzegovina, Montenegro, Serbia and Albania. With more than 70 million inhabitants this region has an important role in enhancing 
geographical continuity in Europe. In the past region has been characterized by conflicts and difficult economic situation and many of these challenges are still being felt today: socio-economic disparities, weak infrastructure networks, underdeveloped energy markets, administrative problems and more.

The European Union Strategy for the Adriatic - Ionian Region was presented in 2014 and builds on the 2000 Adriatic - Ionian Initiative [6]. It regulates smart, sustainable and inclusive growth in the region and defines general objectives such as enhancing the connectivity of the region, competitiveness, economic growth and prosperity, protection of the sea and ecosystems. The stated objectives are planned to be implemented through an Action Plan which requires cooperation of the participating countries governments and consists of 4 essential elements: blue development / growth (innovative maritime and marine growth, sustainable economic development, fisheries, aquaculture, recreational and leisure activities, etc.), region connectivity (transport and energy networks), environmental quality and sustainable tourism.

Each of these components is coordinated by two Member States. Croatia, together with Albania presides over sustainable tourism. The intention is to develop the tourism potential of this region through innovative, sustainable, responsible and quality tourism. It is also important to encourage responsible tourism behavior of all stakeholders in the field of tourism. The following sub-objectives have been defined for sustainable tourism: the diversity of macro-regional tourism products and services together with an effort to reduce seasonality and improve the quality and innovation of tourism offer and to increase sustainable and responsible tourism capacities within the macro-region.

In order to fulfill the goals set out above, the focus is on: diversified tourism offer (products and services) and sustainable and responsible tourism management (innovation and quality).

Although tourism represent one of the fastest growing economic activities in the Adriatic - Ionian region the full potential of the region's natural, cultural, historical and archeological heritage has not been exploited in a sustainable and responsible manner. Improving quality also involves targeting specific groups of tourists, such as the elderly, children and people with disabilities. Apart from the development of specific types of tourism there are many activities that contribute to the diversity of offer and include: development of sustainable tourism routes, development of clusters, networking, care of the cultural heritage of the region and more [6].

Current tourism activities can have a negative impact on the coastal, subcoastal and maritime environment and the ecology. That is why it is important to take sustainable approaches to activities such as responsible use of natural resources, use of clean energy, preservation of the natural and cultural integrity of destinations, etc. Sustainable and responsible tourism management can only be achieved by encouraging innovation through the interaction of different tourism actors, development and clustering of small and medium-sized entrepreneurs (SMEs) at the regional level and through training and education of all tourism actors and alike. 


\section{Blue Growth in Croatia through the development of small shipbuilding}

The coastal part of Croatia is traditionally facing the sea, which is of great economic importance for these regions, but also for the entire Croatian economy. Increased use of marine and coastal space, especially for fisheries, maritime transport, tourism and construction have all increased the pressure on these ecosystems. To ensure sustainable use of resources, an ecosystem-based approach is required, using the concepts of the Integrated Coastal Zone Management (ICM) and Maritime Spatial Planning (MSP) [12]. Both legal frameworks rely on cross-border cooperation, as well as the cooperation of stakeholders in various activities in the coastal and maritime sectors and have the potential to integrate ecosystem services and Blue Growth opportunities in a sustainable way. These are key tools for a balanced decision-making process in sectors that conflict with the use of marine space, and competition for marine space will increase further in the future. Examples include conflicts between traditional users (maritime transport, hydrocarbon exploration and fisheries) and recent activities (tourism / recreation, aquaculture and the renewable energy sector) and the marine environment (especially marine protected areas) [10].

The construction of boats and yachts has a great export potential and connects the entire nautical sector including marinas, charters, services, repairs and restaurants so can become one of the bearers of the Croatian economy. Therefore, it is necessary to include this branch of economy in the economic development strategy.

From 2005 to 2009 small shipbuilding had the fastest growing trend of all industries and during that period the number of small shipyards increased by 500 percent while more than two thousand workers were employed in shipbuilding in the eve of the economic crisis. The rehabilitation and restructuring of the five large Croatian shipyards in the period from 1992 to 2012 cost about 28.5 billion HRK or about 3.72 billion EUR. The fact is that if only a part of this amount had been invested in incentives for small shipbuilding it would have certainly become one of the most powerful manufacturing branches in Croatia today with a very high export rate [2].

Prior to the introduction of excise duties 147 small shipyards were active in Croatia. When the tax levy was abolished in 2012 , there remained only about 30 small shipyards.

The situation on the Croatian nautical market has been much more favorable in recent years and domestic small shipbuilders have also benefited from the growth of nautical tourism which after an unfavorable period caused by the economic crisis and the introduction of excise duties on small vessels began their resurgence.

Small shipbuilding, apart from being the subject of an Industrial Strategy, was not mentioned in the previously adopted Enterprise Strategy 2013-2020. None of these documents recognized the potential of small shipyards in Croatia, although most of them exported or worked for foreign contractors for almost half of their production. It is important for the state to recognize the enormous potential of small shipbuilding, the large numbers of realized revenue and the number of jobs, that this is not just about 
the construction of boats and yachts but the entire nautical sector, including marinas, charters, services, repairs and even restaurants and a number of other activities directly or indirectly related to small shipbuilding.

Small shipbuilding is one of the few manufacturing industries still surviving on the Croatian economic scene decimated by the crisis and recession, while offering domestic and foreign markets indigenous Croatian products based on a centuries-old tradition of boat production. Each year several new models of boats and yachts are introduced to the market with months and years of hard work behind them. Many of these small shipbuilders sell their boats to foreign buyers, and some say openly that as many as 50 percent of their boats go outside Croatia or remain in Croatian ports and marinas but owned by foreign nationals. Some of them successfully break into foreign fairs and international markets, so Croatian boats - both those built for pleasure and sport as well as various working versions - sail the seas of Norway, Sweden, Finland, Australia, Italy, and Romania [9].

The production of vessels on the Croatian side of the Adriatic has a long and rich tradition. Many vessels created on the form of traditional boats from the Adriatic and the Mediterranean are proud to sail the Adriatic. After a long time, this quality and tradition implied, it was decided at the latest session of the Association of Croatian Small Shipbuilding - that brings together almost all Croatian shipbuilders - to initiate the process of obtaining the Croatian Quality Label for boats and products made in Croatia in cooperation with the Croatian Chamber of Economy. This sign should help our domestic shipbuilding industry to better position itself, both in domestic and foreign markets. These are labels used by domestic manufacturers to achieve better recognition and competitiveness in both domestic and foreign markets. This invitation is intended for micro, small and medium-sized enterprises that have recognized it within the Association of Croatian Small Shipbuilding through which domestic boat manufacturers are fighting for their common goals. The Croatian Quality Label should help the domestic shipbuilding to better position themselves in both domestic and foreign markets [13].

\section{European structural and investment programs in Croatia}

The effectiveness of the Mediterranean area innovation in the blue growth sector is lagging behind the European average and lacks transnational and transversal cooperation between the various actors, the so-called quadruple helix in blue growth. A positive example was realized in the Zadar County where the Croatian Chamber of Economy - Zadar County Chamber is one of the holders of three major EU projects [11]. Since January 2018, the Chamber has started implementing the BLUE BOOST project for which money has been secured from the European Interreg Adrion Fund and it has a leading partner role. The goal of the BLUE BOOST project is to stimulate the innovation potential of traditional and new sectoral clusters called Blue growth 
in the Adriatic - Ionian region. As part of the project a network of partners from the seven maritime territories of ADRION will focus on transnational and cross-sectoral cooperation and innovation of maritime clusters through knowledge sharing and a community-based approach. BLUE BOOST will cover the implementation of Blue labs, workshops and hackathons and provide $€ 315,000$ for around 35 small projects funded by the Blue Innovation Project Voucher scheme in order to foster and drive the innovation capabilities of micro, small and medium-sized enterprises, start-ups for traditional sectors of Blue Growth (fisheries and shipbuilding) and new ones (blue technologies, including aquaculture, green shipbuilding, robotics, new materials, etc.) in the Adriatic - Ionian area.

BLUE BOOST will ultimately support the Transnational Innovation Networking Strategy and the Joint Action Plan for the long-term capitalization of project results for maritime clusters in seven projects in the Adriatic - Ionian area and beyond. The project is funded under the INTERREG ADRION Program and has an implementation period from 1 January 2018 to 31 October 2019.

The second project of the Zadar County Chamber [9], called 4helix +, started in February 2018 with money from the European Interreg Mediterranean Fund. The Zadar County Chamber is one of nine partners, with the leading Regional Development Agency of the Marche Region SVIM in Italy. The 4helix + project (empowering 4 spirals of the Mediterranean maritime clusters through the open source acces / knowledge-sharing and community-based approaches for the benefit of the Blue Growth of the Mediterranean) focuses on stimulating and financing innovation within the Blue Growth Sector in the Mediterranean (MED) area.

The project intends to improve the gap between the eight Mediterranean regional maritime clusters on the one hand and within their four spirals on the other. This is predicted to be achieved through an open source acces, knowledge-sharing and community-based approach wich is the result of collaboration with so-called "new innovation agents" and the cultural and creative industries. The mentioned project will enhance the transnational innovation process in the so-called blue traditional and emerging sectors in eight MED regions, establishing and organizing cyberspaces, boot camps, transnational brokerage events, regional information days and awarding innovation vouchers. The cyberspace project will enable the merger between blue micro, small, medium and start-up companies and new innovation agents (fablabs, coworking spaces, creative hubs, etc.) and the cultural and creative industries (high skilled enterprises, research and development (R\&D) centers, etc.).

Through the Innovation Voucher Scheme at least 48 Blue Economy projects will be awarded totallying EUR 480,000. Through its transnational partner network and objectives, the project will contribute to relevant EU macro-regional strategies and innovation policies.

The third project implemented by the Zadar Chamber [9] is MISTRAL. Namely, the innovation efficiency of the Mediterranean area in the blue growth sector lags behind the European average and lacks transnational and transversal cooperation between the 
various actors, the so-called quadruple helix in blue growth. The aim of MISTRAL is to strengthen a transnational partnership of eight countries ( 2 ministries, 8 regions, 5 clusters, 3 research and technology organizations and other organizations) to make the sea knowledge and sustainable innovation key drivers of blue growth and to support the Mediterranean clusters to become excellent knowledge brokers for a growing blue economy. The aim is also to create and implement sustainable development trajectories aligned with the smart specialization strategies of the Mediterranean regions. The special purpose is to improve the innovation performance of at least 300 SMEs with at least 100 professionals through the Clustering Innovation Service Package for sectors and blue growth operators. That means a lot of benefit from transnational activities and exchange capacity building programs. MISTRAL has the ambition to develop as a broader vision of governance in the blue growth sector towards 2020. The total budget of the project is EUR 4.8 million and the co-financing from ERDF and IPA II funds is EUR 4.1 million. The project will last 48 months, from 1 February 2018 to 31 January 2022 [9].

The efforts of the Croatian Chamber of Economy - Rijeka County Chamber should also be emphasized, that have organized in cooperation with the Kingdom of Norway as a partner country the commercial manifestation AdRia4Blue in Rijeka to promote the Blue Economy and Sustainable Development. The Croatian economy and especially the economy of Rijeka and the Primorje-Gorski Kotar County (PGŽ) have traditionally been oriented towards the sea and activities related to the sea, the so-called blue economy. It has been pointed out that the City of Rijeka as a regional center and a maritime and land transport hub should become a traditional meeting place while special attention was focused on blue growth. This is a long-term strategy to support sustainable growth in the maritime sector as a whole and is a driver within the European economy with great potential for innovation and development.

In the area of PGŽ there is a lack of accommodation facilities and a sufficient number of coastal berths for sports and tourism related vessels. With the further construction and landscaping of the entire coastal strip and coastal promenade in the eastern part of the city along a wide stretch from Brajdica to Martinscica, the new nautical port Brajdica will represent a logical content start of an attractive coastal move. It is also necessary to build docks for mega yachts that the PGŽ cannot accept in its current capacities due to the lack of such berths. The arrival of mega yachts would attract a considerable number of domestic and foreign boaters, who would have to provide other facilities such as catering facilities, nautical equipment stores, boat services and gas stations that are currently significantly smaller in number than needed. This would result in significant development of nautical tourism in the Kvarner area and would lay down strong foundations for achieving the blue growth and sustainable development of the PGŽ. 


\section{Development of nautical marinas and anchorages - capacities and business activities of nautical tourism ports in 2018}

Nautical tourism is a subsector of the coastal and maritime tourism, which is promoted as an important source of job creation and growth in the Blue Economy. The nautical tourism port is a tourism industry facility that in business, spatial, construction and functional sense provides conditions to meet the needs of nautical tourists. Although nautical tourism still represents only a smaller part of the total Croatian tourist traffic, this branch of tourism is developing and growing at a faster rate. The favorable geographical position, cleanliness of the sea and the indentedness of the Croatian Adriatic coast as well as more than a thousand islands with countless bays attract more and more boaters every year.

For boaters, anchoring is not just a necessity to shelter from a storm or vessel engine failure, but often the very purpose of navigation. In 2009 the Ministry of the Sea, Transport and Infrastructure adopted the Strategy for the Development of Nautical Tourism for the period 2009-2019 which identified low competitiveness of Croatia in nautical tourism. Compared to the Mediterranean neighboring countries, apart from natural factors such as the clean sea and favorable climate, the biggest drawback of the whole Croatian nautical offer is the capacity, followed by the nautical tourism ports equipment and the accompanying catering offer.

The Central Bureau of Statistics (CBS) conducted a survey in 2018 that included 142 nautical tourism ports (including 14 dry marinas) and 70 other nautical tourism ports on the Croatian coast. The total sea surface area was $4075400 \mathrm{~m} 2$ with 17274 berths [3].

According to CBS most nautical ports are located in the Zadar County, 39 followed by 29 in the Šibenik-Knin and Split-Dalmatia counties, 25 in the Primorje-Gorski Kotar, 12 in Istria and 8 in the Dubrovnik-Neretva County while the largest number of berths or almost 4,000 are located in the Šibenik-Knin County, followed by 3,900 in the Zadar County ports.

Table 1 - Nautical tourism ports in 2018 [15]

\begin{tabular}{|l|c|c|c|c|c|c|c|c|c|}
\hline & \multirow{2}{*}{ Total } & Anchorage & Mooring & $\begin{array}{c}\text { Land } \\
\text { marina }\end{array}$ & $\begin{array}{c}\text { Marina, } \\
I^{s t} \\
\text { category }\end{array}$ & $\begin{array}{c}\text { Marina, } \\
2^{\text {nd }} \\
\text { category }\end{array}$ & $\begin{array}{c}\text { Marina, } \\
3^{\text {rd }} \\
\text { category }\end{array}$ & $\begin{array}{c}\text { Marina, } \\
\text { categorised } \\
\text { and marked } \\
\text { by anchors }\end{array}$ & $\begin{array}{c}\text { Uncategorised } \\
\text { nautical ports }\end{array}$ \\
\hline & & & & & & & & & \\
\hline $\begin{array}{l}\text { Republic } \\
\text { of Croatia }\end{array}$ & $\mathbf{1 4 2}$ & 62 & 6 & 14 & 5 & 14 & 17 & 22 & 2 \\
\hline $\begin{array}{l}\text { County of } \\
\text { Primorje- } \\
\begin{array}{l}\text { Gorski } \\
\text { kotar }\end{array}\end{array}$ & $\mathbf{2 5}$ & 8 & 2 & 5 & 1 & 2 & 3 & 4 & - \\
\hline $\begin{array}{l}\text { County of } \\
\text { Zadar }\end{array}$ & $\mathbf{3 9}$ & 25 & 2 & 4 & - & 4 & 4 & - & \\
\hline
\end{tabular}




\begin{tabular}{|l|c|c|c|c|c|c|c|c|c|}
\hline $\begin{array}{l}\text { County of } \\
\text { Sibenik- } \\
\text { Knin }\end{array}$ & $\mathbf{2 9}$ & 14 & - & 1 & 2 & 2 & 5 & 5 & - \\
\hline $\begin{array}{l}\text { County } \\
\text { of Split- } \\
\text { Dalmatia }\end{array}$ & $\mathbf{2 9}$ & 14 & 1 & 3 & - & 3 & 3 & 5 & - \\
\hline $\begin{array}{l}\text { County of } \\
\text { Istria }\end{array}$ & $\mathbf{1 2}$ & - & 1 & - & 2 & 1 & 2 & 6 & - \\
\hline $\begin{array}{l}\text { County of } \\
\text { Dubrovnik- } \\
\text { Neretva }\end{array}$ & $\mathbf{8}$ & 1 & - & 1 & - & 2 & - & 2 & 2 \\
\hline
\end{tabular}

The total income realised in nautical ports in 2018 amounted to 857 million HRK (Croatian kuna). Out of that, 618 million HRK were realised from mooring rents that is $72.2 \%$ of the total realised income. As compared to 2017 , the total revenue was by $2.7 \%$ higher and the berth rental revenue was by $7.1 \%$ higher. Author Alkier (2019) points out that almost 484 million HRK or by $7.6 \%$ more than in 2017 was generated from permanent berths at total berth rentals, while an amount of almost 135 million HRK or by $5.4 \%$ more was generated from transit. In the period 2014-2018 the total income of nautical tourism ports reached a $19.54 \%$ increase, of which the major portion came from repair services $(+44.31 \%)$, transit $(+29.77 \%)$, other incomes $(20.11 \%)$, and mooring rents $(17.11 \%)$ of which $29.77 \%$ from transit moorings, and $14.02 \%$ from permanent moorings [1].

In the structure of total revenues of nautical tourism ports in 2018, other revenues amounting to 19 million HRK fell by $12 \%$ compared to 2017 . In the Adriatic counties [3] the highest nautical ports revenue within the area amounted to 225 million HRK and was recorded by the Šibenik-Knin County, which is by 5.4 percent lower than in 2017. As opposed to the revenue of these ports, the Split-Dalmatia County revenue grew by 10 percent to reach 198 million HRK. With revenues of 175.6 million HRK or by 3.5 percent higher there follow nautical ports of the Zadar County, those of the Primorje-Gorski Kotar County with an income of 108 million HRK or by 2.6 percent higher, the ports of the Istria County with 101.2 million HRK that retained the level of 2017, while the ports of the Dubrovnik-Neretva County with revenues of almost 50 million HRK represent the highest increase recorded among all counties or $22.2 \%$.

Table 2 - Income realised by nautical ports, not including VAT [15]

\begin{tabular}{|c|c|c|c|}
\hline & \multicolumn{2}{|c|}{ Income, in thousand HRK } & \multirow{2}{*}{\begin{tabular}{c} 
Indices \\
I-XII 2018 \\
\cline { 2 - 3 }
\end{tabular}} \\
\cline { 2 - 3 } & 2017 & $\mathbf{2 0 1 8}$ & \\
\hline & & & I-XII 2017 \\
\hline Republic of Croatia & $834022^{1)}$ & 856550 & 102,7 \\
\hline Renting of moorings & $577047^{1)}$ & 618150 & 107,1 \\
\hline Stationed & $449309^{1)}$ & 483553 & 107,6 \\
\hline
\end{tabular}




\begin{tabular}{|c|c|c|c|}
\hline In transit & $127738^{1)}$ & 134597 & 105,4 \\
\hline Maintaining services & 65862 & 69761 & 105,9 \\
\hline Other income & 191113 & 168639 & 88,2 \\
\hline $\begin{array}{l}\text { County of Primorje- } \\
\text { Gorski kotar }\end{array}$ & $105186^{1)}$ & 107878 & 102,6 \\
\hline Renting of moorings & $78237^{1)}$ & 83087 & 106,2 \\
\hline Stationed & $66916^{1)}$ & 72012 & 107,6 \\
\hline In transit & 11321 & 11075 & 97,8 \\
\hline Maintaining services & 5993 & 6437 & 107,4 \\
\hline Other income & 20956 & 18354 & 87,6 \\
\hline County of Zadar & 169715 & 175669 & 103,5 \\
\hline Renting of moorings & 123362 & 126211 & 102,3 \\
\hline Stationed & 104292 & 110165 & 105,6 \\
\hline In transit & 19070 & 16046 & 84,1 \\
\hline Maintaining services & 16178 & 13278 & 82,1 \\
\hline Other income & 30175 & 36180 & 119,9 \\
\hline $\begin{array}{l}\text { County of Šibenik- } \\
\text { Knin }\end{array}$ & 237790 & 225002 & 94,6 \\
\hline Renting of moorings & 126878 & 139107 & 109,6 \\
\hline Stationed & 100978 & 107526 & 106,5 \\
\hline In transit & 25900 & 31581 & 121,9 \\
\hline Maintaining services & 17486 & 21598 & 123,5 \\
\hline Other income & 93426 & 64297 & 68,8 \\
\hline $\begin{array}{l}\text { County of Split- } \\
\text { Dalmatia }\end{array}$ & 180091 & 197852 & 109,9 \\
\hline Renting of moorings & 129149 & 143226 & 110,9 \\
\hline Stationed & 87002 & 98415 & 113,1 \\
\hline In transit & 42147 & 44811 & 106,3 \\
\hline Maintaining services & 19481 & 20154 & 103,5 \\
\hline Other income & 31461 & 34472 & 109,6 \\
\hline County of Istria & $101247^{1)}$ & 101275 & 100,0 \\
\hline Renting of moorings & 85 9291) & 85714 & 99,7 \\
\hline
\end{tabular}




\begin{tabular}{|c|c|c|c|}
\hline Stationed & $72504^{1)}$ & 72569 & 100,1 \\
\hline In transit & $13425^{1)}$ & 13145 & 97,9 \\
\hline Maintaining services & 4893 & 5245 & 107,2 \\
\hline Other income & 10425 & 10316 & 99,0 \\
\hline $\begin{array}{l}\text { County of Dubrovnik- } \\
\text { Neretva }\end{array}$ & 39993 & 48874 & 122,2 \\
\hline Renting of moorings & 33492 & 40805 & 121,8 \\
\hline Stationed & 17617 & 22866 & 129,8 \\
\hline In transit & 15875 & 17939 & 113,0 \\
\hline Maintaining services & 1831 & 3049 & 166,5 \\
\hline Other income & 4670 & 5020 & 107,5 \\
\hline
\end{tabular}

There were 13617 vessels recorded in nautical ports on December 31, 2018, which is by $1.4 \%$ more than on December 31,2017 . There were $86.2 \%$ of vessels using berth at sea and $8 \%$ of vessels used the sole location onshore [3]. By the type, among vessels on permanent berth the largest number referred to sail boats $(50.1 \%)$, followed by motor yachts (46.1\%), and other vessels (3.8\%). The largest number of vessels on permanent berth was under the Croatian flag, $44.0 \%$. These were followed by vessels flying the flag of Austria (15.8\%), Germany (15.2\%), Slovenia (5.1\%), Italy (4.2\%), and the United Kingdom (2.2\%).

In contrast to the increase in permanent moorings, vessels in transit in the Croatian territorial sea numbered by 3.8 percent less in 2018 than in 2017 or precisely 194,164. According to the type of vessels in transit with sea berth, the majority were sailing yachts $(67.3 \%)$, followed by motor yachts (28.3\%), and other vessels (4.4\%). In 2018, most vessels in transit were from Croatia (47.7\%), Italy (13.9\%), Germany (12.8\%), Austria (6.6\%) and Slovenia (3.8\%), accounting for $84.8 \%$ vessels out of the total number of vessels in transit [3].

Increasing the number of berths and quality of service are real prerequisites for the development of nautical tourism. It is clear that for successful development of nautical tourism anchoring areas with adequate facilities should be provided. Proper nautical infra- structure and supra-structure as well as an increase in the number of anchorages under concession are prerequisites for the development of nautical tourism. The number of nautical anchorages under concession in Croatia is increasing which further contributes to the increase in the safety of boaters. 


\section{Conclusion}

The entrepreneurial potential of the blue economy for Croatia and Europe is enormous. At present, blue economy as the newest development concept is becoming an important driving force for achieving sustainable blue development. Today focus on the blue economy in Croatia needs more responsibilities, in the way to connect all stakeholders who are involved in coastal and marine managing. European structural funds can help with investments especially in some activities like small shipbuilding, mariculture and ports. Throughout the past, small shipbuilding has developed a lot of problems. Some of them are the result of objective but also of subjective reasons. In the future the Croatian Quality Label should help domestic shipbuilding to get better position on both domestic and foreign markets.

A positive example has been realized in the Zadar County where the Croatian Chamber of Economy - Zadar County Chamber is one of the holders of three major EU projects. The Primorsko-goranska County Chamber is also very active. In cooperation with the Kingdom of Norway as a partner country, it recently organized the AdRia4Blue commercial manifestation in Rijeka to promote the Blue Economy and Sustainable Development.

Croatia has an important role at the EUSAIR where Croatia, together with Albania presides over the group for sustainable tourism. One of the intentions of the EUISAIR association is to develop the tourism potential of this region through innovative, sustainable tourism achives.

Nautical tourism as a growing part of the tourism industry, realised an income of EUR 11,58 million in 2018. It is a logical conclusion that the importance of further investing in the nautical sector is underlined with stimulating the development of small shipbuilding. Nautical tourism as a subsector of the coastal and maritime tourism is an important source of job creation and growth in the Croatian Blue Economy. It is clear that nautical tourism achives a lot of benefits and with this in mind some of the income can be used for marine protection.

In the future, it is necessary to explore the great opportunities and potentials for realizing the sustainable growth in this sector, since it has a strong impact on the overall Croatian economy. 


\section{References}

1. Alkier, R. (2019) Perspectives of Development of Luxury Nautical Tourism in the Republic of Croatia. Pomorski zbornik. Vol.56 No.1. 109-124.

2. Carić Herceg, S. (2016). Veliki uzlet male hrvatske brodogradnje bez pomoći države. Nacional. 945 (06-12). Available from: https://www.nacional.hr/dossier-veliki-uzlet-male-hrvatske-brodogradnjebez-pomoci-drzave-2/ [Accessed 29th June 2019].

3. Državni zavod za statistiku Republike Hrvatske. (2019) Nautički turizam: Kapaciteti i poslovanje luka nautičkog turizma u 2018. Godina: LV. Broj: 4.3.4. Avaliable from: https://www.dzs.hr/ Hrv_Eng/publication/2018/04-03-04_01_2018.htm [Accessed 7th December 2019].

4. European Commission. (2019) The E $\bar{U}$ Blue Economy Report 2019. https://ec.europa.eu/ knowledge4policy/publication/eu-blue-economy-report-2019 en [Accessed 10th December 2019].

5. European Commission. (2017) Blue growth. Available from: $\bar{h}$ ttps://ec.europa.eu/maritimeaffairs/ policy/blue_growth_en [Accessed 28th June 2019].

6. European Commission. (2014) The EU Strategy for the Adriatic and Ionian Region (EUSAIR). Available from: https://www.msp-platform.eu/practices/eu-strategy-adriatic-and-ionian-regioneusair [Accessed 10th December 2019].

7. Europska Komisija. (2014) COM (2014) 86 final (2014/C 451/10): Komunikacija komisije Europskom parlamentu, Vijeću, Europskom gospodarskom i socijalnom odboru i Odboru regija - Europska strategija za veći rast i radna mjesta u obalnom i pomorskom turizmu. Bruxelles.

8. Group of authors (2018). Successful blue economy examples with an emphasis on international perspectives. Frontiers in Marine Science. 1-14. Available from: http://dx.doi.org/10.3389/ fmars.2019.00261 [Accessed 7th December 2019].

9. Hrvatska gospodarska komora. (2019) Početak provedbe projekta Europske unije 4helix+. Available from: https://www.hgk.hr/hrvatska-gospodarska-komora/projekt-4helix [Accessed 29th June 2019].

10. Institut Plavi svijet. (2019) Morska zaštićena područja. Available from: https://www.plavi-svijet. org/zastita/morska-zasticena-podrucja-i-prostorno-planiranje-na-moru/ [Accessed 28th June 2019].

11. Klarica, S. (2018) 7.8 milijuna eura za sektor plavog rasta. Zadarski list. 12/18.

12. Available from: https://www.zadarskilist.hr/clanci/30122018/gospodarstvo-78-milijuna-eura-zasektor-plavog-rasta [Accessed 29th June 2019].

13. Kovačić, M., Zekić, A., Rukavina, B. (2016) Maritime Spatial Planning in Croatia - Necessity or Opportunity for Balanced Development, Pomorstvo, Journal of Maritime Studies, 2016, 30(1). 82-87.

14. More. (2019) Moja brodica. Available from: https://www.more.hr/blog/hrvatska-malabrodogradnja/ [Accessed 28th June 2019].

15. https://www.dzs.hr/Hrv_Eng/publication/2018/04-03-04_01_2018.htm 